\title{
PENGGUNAAN MODEL PEMBELAJARAN PROBLEM BASED LEARNING BERBANTUAN KARTU "SULANG MAYA" DALAM MENINGKATKAN AKTIVITAS DAN HASIL BELAJAR PENDIDIKAN AGAMA HINDU SISWA KELAS VII A SMP NEGERI 1 BANGLI TAHUN PELAJARAN 2018/2019
}

\author{
Oleh: \\ I Nengah Asrama Juta Ningrat, S.Ag, M.Fil.H dan Ayu Veronika Somawati, M.Fil.H. \\ SMP Negeri 1 Bangli dan STAHN Mpu Kuturan Singaraja \\ jutaningrat@gmail.com dan ayuvero90@gmail.com
}

\begin{abstract}
This study aims to increase student activity and learning outcomes through the use of the use of the Problem Based Learning Model assisted by Sulang-Maya cards in class VII A students of SMP Negeri 1 Bangli in the 2018/2019 learning year in the subject of Hindu Religious Education. Sulang-Maya card is an acronym for rearranging the card-based yadnya learning material which contains pictures of the implementation of the yadyna ceremony. The steps for using the Sulang-Maya card are as follows: a) the teacher provides an overview of yadnya learning material in the form of attractive illustrations and pictures, b) the teacher presents the yadnya learning material in the form of card pieces and distributes pictures of the various yadny a implementation to students, c) students in groups actively pair the pictures of the yadnya ceremony which are distributed according to the parts of the Panca Yadnya,d) the teacher intensively provides explanations to students so that students are active in doing assignments, e) students and their group members actively explain the results of their group work in front of the class, and f) the teacher reflects on the results of learning activities. Data collection techniques in this study were tests and observations, and the data from the research results were analyzed using qualitative descriptive analysis. The results showed that through the use of the Problem Based Learning Model assisted by Sulang-Maya cards in class VII A students of SMP Negeri 1 Bangli in the 2018/2019 learning year, it could increase activity and learning outcomes in Hindu Religious Education subjects.
\end{abstract}

\section{PENDAHULUAN}

Pembelajaran agama Hindu berperan untuk pembentukan sikap dan perilaku siswa yang berkarakter dan pengembangan intelektual, sosial serta emosional siswa yang berperan sebagai kunci penentu menuju keberhasilan dalam mempelajari suatu bidang tertentu. Selain itu pula sejalan dengan pengembangan
Kurikulum 2006 kedalam kurikulum 2013 peserta didik dirancang tidak hanya bertambah pengetahuanya, tetapi juga meningkat keterampilanya dan semakin mulia keperibadinya.

Penggunaan Model Pembelajaran Problem Based Learning Berbantuan Kartu "Sulang Maya” Dalam Meningkatkan Aktivitas Dan Hasil Belajar Pendidikan Agama Hindu Siswa Kelas VII A SMP Negeri 1 Bangli Tahun Pelajaran 2018/2019

SMP Negeri 1 Bangli dan STAHN Mpu Kuturan I Nengah Asrama Juta Ningrat, S.Ag, M.Fil.H dan Singaraja Ayu Veronika Somawati, M.Fil.H. 
Melalui pembelajaran agama Hindu diharapkan dapat membentuk keterampilan beragama dan terwujud sikap beragama peserta didik yang seimbang, mencakup hubungan manusia dengan penciptanya, sesama manusia dan hubungan manusia dengan alam sekitarnya.

Mengingat begitu pentingnya pendidikan agama Hindu bagi peserta didik, hal ini merupakan sebuah tantangan bagi guru yang mengajar agama Hindu untuk mampu memfasilitasi siswa supaya dapat belajar agama Hindu dengan baik dan menyenangkan. Guru agama Hindu dituntut untuk mampu mendesain pembelajaran dengan model yang tepat pada setiap jenjang pendidikan yang menyesuaikan dengan tuntutan materi pembelajaran. Penggunaan model dalam pembelajaran merupakan sebuah strategi yang dapat ditempuh oleh guru dalam melakukan pendekatan belajar.

Proses pembelajaran akan sangat efektif apabila guru melaksanakannya dengan memahami peran, fungsi mata pelajaran yang diampunya. Pemahaman akan keefektipan hal-hal itu juga ditentukan oleh kemampuan guru untuk merubah model pembelajaran dari yang kurang efektif dan kurang menyenangkan menjadi model pembelajaran yang efektif dan menyenangkan peserta didik, sesuai dengan yang diamanatkan oleh Permendikbud No. 22 tahun 2016 Tentang Standar Proses Pendidikan Dasar dan Menengah.

Harapan tumbuhnya sifat kreatif dan inovatif para pendidik dalam pendidikan agama Hindu untuk praktik pembelajaran dalam pemahaman dewasa ini masih belum optimal. Hal ini tampak dari pelaksanaan pembelajaran yang tidak lebih dari kegiatan pembelajaran yang belum menggunakan media-media yang menarik minat siswa untuk mempelajari agama Hindu serta masih konvensional atau berpusat pada guru (teacher centered) sehingga belum menyentuh peserta didik itu sendiri. Selain itu proses pembelajaran hanya bersifat menghabiskan materi sesuai dengan tuntutan kurikulum. Hal ini sesuai dengan kenyataan yang ada di SMP Negeri 1 Bangli dalam proses pembelajaran Agama Hindu yaitu :

1) Adanya pandangan siswa bahwa Pendidikan Agama Hindu selalu diidentikkan dengan bentuk-bentuk pembelajaran teoritis berupa hapalan fakta atau konsep-konsep yang dalam proses pembelajaran yang didominasi oleh metode ceramah dan tanya jawab yang selalu menjadi pilihan guru. Akibatnya siswa tidak bersemangat mengikuti pelajaran agama Hindu karena hanya menghafal materi yang ada dalam buku dan aktivitas belajar rendah.

2) Pembelajaran berorientasi pada buku paket atau teks pelajaran yang monoton dan guru kurang kreatif dalam memilih sumber belajar hanya fokus pada materi yang ada pada buku dan kurang dengan situasi aktual dan pengalaman yang dimiliki oleh siswa itu sendiri.

3) Proses pembelajaran masih konvensional (teacher concerd). Pembelajaran yang berpusat pada Guru (teacher concerd) yang selama ini diterapkan menyebabkan partisipasi siswa dalam pembelajaran rendah karena siswa hanya berperan sebagai pendengar, sehingga siswa hanya menerima apa yang diberikan oleh guru dan menyerap informasi yang ada dalam buku tanpa ada pengembangan.

Penggunaan Model Pembelajaran Problem Based Learning Berbantuan Kartu "Sulang Maya” Dalam Meningkatkan Aktivitas Dan Hasil Belajar Pendidikan Agama Hindu Siswa Kelas VII A SMP Negeri 1 Bangli Tahun Pelajaran 2018/2019

SMP Negeri 1 Bangli dan STAHN Mpu Kuturan I Nengah Asrama Juta Ningrat, S.Ag, M.Fil.H dan Singaraja Ayu Veronika Somawati, M.Fil.H. 
VOLUME 8 NOMOR 1 MARET 2021

ISSN : 2355-5696 (CETAK)

ISSN : 2655-0156 (ONLINE)

http://ejournal.ihdn.ac.id/index.php/GW
Permasalahan-permasalahan

tersebut berimplikasi pada hasil evaluasi proses pembelajaran pendidikan agama Hindu yang telah dilaksanakan di SMP Negeri 1 Bangli, yaitu hasil belajar siswa belum dapat memenuhi KKM yang telah ditentukan dan daya serap klasikal masih di bawah rata-rata KKM. KKM yang ditetapkan sesuai Kurikulum Satuan Pendidikan (KTSP) di kelas VII SMP N 1 Bangli adalah 72, sedangkan siswa yang beragama Hindu sejumlah 28 orang baru mencapai hasil evaluasi pembelajaran ratarata 65. Melihat permasalahan tersebut maka dalam proses pembelajaran diperlukan inovasi dan kreatifitas yang optimal. Penggunaan model dan strategi dalam proses pembelajaran inovatif, kreatif dan menyenangkan menjadi isu dan bahan kajian yang terus dikembangkan.

Model pembelajaran agama Hindu merupakan hal yang sangat esensial menyangkut masalah pendidikan dalam upaya membentuk pengetahuan siswa secara realistis. Nilai guna tersebut didasarkan pada kemampuan model dalam membantu siswa mempermudah memahami materi yang disajikan oleh guru. Melalui model pembelajaran akan terjadi penguatan materi dalam struktur kognitif siswa yang memberi gambaran lebih konkrit. Oleh karenanya guru agama Hindu sebagai fasilitator dan penyelenggara pendidikan dituntut untuk memikirkan dan mengupayakan model-model pembelajaran yang tepat guna dalam proses pembelajaran, agar terjadi interaksi yang optimal antara siswa dengan komponen-komponen lainnya. Model pembelajaran yang dapat digunakan dalam kegiatan pembelajaran Agama Hindu yaitu, model pembelajaran sebagaimana dimaksud pada Permendikbud Nomor 103
Tahun 2014 dan Permendibud Nomor 22 Tahun 2016 adalah model pembelajaran yang

menonjolkan aktivitas dan kreativitas, menginspirasi, menyenangkan dan berprakarsa, berpusat pada siswa, otentik, kontekstual, dan bermakna bagi kehidupan siswa sehari-hari, antara lain sebagai berikut :

a) Model Penyingkapan (Discovery Learning)

Model discovery learning, memberikan kesempatan kepada pelajar untuk menyikapi atau mencari tahu tentang suatu masalah-masalah yang ada tetapi belum mengemuka dan menemukan solusinya berdasarkan hasil pengolahan informasi yang dicari dan dikumpulkan sendiri sehingga pelajar memiliki pengetahuan baru yang dapat digunakan untuk melakukan pemecahan masalah yang relevan dengan kehidupan sehari-hari. Dengan sintak pembelajaran sebagai berikut: memberi stimulus (stimulation), mengidentifikasi masalah (problem statement), mengumpulkan data (data collecting), mengolah data (data processing), memverifikasi (verification) dan menyimpulkan (generalization).

b) Model Inquiry

Model Inquiri merupakan model penemuan merupakan suatu kegiatan belajar yang melibatkan secara maksimal seluruh kemampuan peserta didik untuk mencari dan menyelidiki secara sistemik, kritis, logis, dan analitis, sehingga mereka dapat merumuskan sendiri penemuannya. Peserta didik dilatih dapat mengumpulkan informasi tambahan, membuat hipotesis dan mengujinya.

Penggunaan Model Pembelajaran Problem Based Learning Berbantuan Kartu "Sulang Maya” Dalam Meningkatkan Aktivitas Dan Hasil Belajar Pendidikan Agama Hindu Siswa Kelas VII A SMP Negeri 1 Bangli Tahun Pelajaran $2018 / 2019$

SMP Negeri 1 Bangli dan STAHN Mpu Kuturan I Nengah Asrama Juta Ningrat, S.Ag, M.Fil.H dan Singaraja 
Peran guru selain sebagai pengarah dan pembimbing, juga dapat menjadi sumber informasi data yang diperlukan. Berikut alur kegiatan pembelajaran dalam menggunakan model penemuan yaitu: mengamati berbagai fenomena, mengajukan pertanyaan tentang, mengajukan dugaan atau kemungkinan jawaban, mengumpulkan data yang terakait dengan dugaan atau pertanyaan yang diajukan, dan merumuskan kesimpulan-kesimpulan berdasarkan data yang telah diolah atau dianalisis.

c) Model Project-based Learning

Model pembelajaran berbasis projek, menekankan pada pemberian kesempatan kepada peserta didik untuk belajar dari kegiatan melakukan suatu proyek yang menghasilkan suatu karya melalui pengembangan pengetahuan, sikap, nilai, dan keterampilan yang berguna bagi kehidupannya di masyarakat. Alur kegiatan pembelajaran dalam PJBL sebagai berikut: menyiapkan pertanyaan atau penugasan proyek, mendesain perencanaan proyek, menyusun jadwal sebagai langkah nyata dari sebuah proyek, memonitor kegiatan dan perkembangan proyek, menguji hasil dan mengevaluasi kegiatan/pengalaman.

d) Model Problem-based Learning

Model pembelajaran Problem-based Learning adalah pembelajaran yang menyajikan pemecahan masalah kontekstual, sehingga merangsang pelajar agar mampu memecahkan masalah dunia nyata (real world). Pada pembelajaran ini melatih pelajar terampil menyelesaikan masalah. Oleh karenanya pembelajarannya selalu dihadapkan pada permasalahanpermasalahan kontekstual. Alur kegiatan PBL sebagai berikut: mengorientasi peserta didik pada masalah; mengorganisasikan kegiatan pembelajaran; membimbing penyelidikan mandiri dan kelompok; mengembangkan dan menyajikan hasil karya; dan analisis dan evaluasi proses pemecahan masalah. Dalam penelitian ini, penulis menggunakan model Problem-based Learning, mengingat karakter materi yadnya sangat relevan sintak-sintak pembelajaranya menggunakan model Problem-based Learning.

Joyce \& Weil berpendapat bahwa model pembelajaran adalah suatu rencana atau pola yang dapat digunakan untuk membentuk kurikulum (rencana pembelajaran yang panjang), merancang bahan-bahan pembelajaran, dan membimbing pembelajaran dikelas atau yang lain (Rusman, 2013). Setiap model pembelajaran ada keunggulan dan kelemahannya, untuk mengatasi kelemahan dari sebuah model pembelajaran bergantung kepada bagaimana guru mengimplementasikan model pembelajaran tersebut dalam bentuk kemasan yang lebih efektif dan efisien (Abdullah, 2017)

Pembelajaran dengan model PBL (Problem Based Learning) merupakan model pembelajaran yang melibatkan siswa dalam memecahkan masalah nyata. Kelebihan model ini salah satunya adalah mampu menyebabkan motivasi dan rasa ingin tahu siswa menjadi meningkat (Wahyuningsih, 2019). Selain itu, dalam model pembelajaran ini guru memandu siswa menguraikan rencana pemecahan masalah menjadi tahap-tahap kegiatan;

Penggunaan Model Pembelajaran Problem Based Learning Berbantuan Kartu “Sulang Maya” Dalam Meningkatkan Aktivitas Dan Hasil Belajar Pendidikan Agama Hindu Siswa Kelas VII A SMP Negeri 1 Bangli Tahun Pelajaran 2018/2019

SMP Negeri 1 Bangli dan STAHN Mpu Kuturan I Nengah Asrama Juta Ningrat, S.Ag, M.Fil.H dan Singaraja Ayu Veronika Somawati, M.Fil.H. 
guru memberi contoh mengenai penggunaan keterampilan dan strategi yang dibutuhkan supaya tugas-tugas tersebut dapat diselesaikan guru menciptakan susasana kelas yang fleksibel dan berorientasi pada upaya penyelidikan oleh siswa (Indrawati Romadhoni, 2017)

Semua uraian di atas menunjukkan hal-hal yang perlu dalam upaya meningkatkan kesesuaian pembelajaran problem based learning yang akan dilakukan dan prestasi belajar siswa seperti penguasaan strategi-strategi ajar; penguasaan model-model pembelajaran, penguasaan teori-teori belajar; penguasaan teknik-teknik tertentu; penguasaan peran, fungsi serta kegunaan mata pelajaran. Apabila betul-betul guru menguasai dan mengerti tentang hal-hal tersebut dapat diyakini bahwa prestasi belajar peserta didik pada mata pelajaran pendidikan agama Hindu tidak akan rendah. Namun kenyataannya prestasi belajar siswa kelas VII A baru mencapai nilai rata-rata KKM 65. Jumlah KKM yang ditentukan dalam Kurikulum Satuan Pendidikan (KTSP) di kelas VII adalah 72. Dengan mengacu pada Permendikbud Nomor 23 tahun 2016 tentang Penilaian dan Panduan Penilaian tingkat SMP revisi 2017 maka, rentangan nilai KKM, angka 65 berada pada katagori D sehingga dapat dikatakan bahwa hasil belajar siswa masih rendah. Berdasarkan rentangan nilai KKM, hasil belajar dikatakan sedang apabila berada pada rentangan 72-81 dengan kategori $\mathrm{C}$, dan dikatakan tinggi apabila berada pada rentangan nilai $82 \mathrm{ke}$ atas.

Melihat kesenjangan antara harapan-harapan yang telah disampaikan dengan kenyataan di lapangan sangat jauh berbeda, dalam upaya memperbaiki mutu pendidikan utamanya pada mata pelajaran pendidikan agama Hindu, sangat perlu kiranya dilakukan perbaikan cara pembelajaran. Salah satunya adalah perbaikan pembelajaran dengan menggunakan model pembelajaran Problem Based Learning berbantuan kartu Sulang-Maya. Sulang Maya adalah singkatan dari susun ulang materi yadnya. Peserta didik diberikan kartu-kartu yang berisikan gambar upacara yadyna, setelah itu peserta didik diberikan kesempatan untuk mnyusun dan menjelaskan kembali mengenai upacara yadnya yang terdapat dalam kartu gambar tersebut berdasarkan pengetahuan dan bahasa mereka sendiri. Model pembelajaran ini bertujuan agar peserta didik belajar dari masalah dan mampu memecahkan masalah yang dialami untuk pencapain tujuan dalam proses pembelajaran secara efektif dan efesien berbasis aktivitas. Oleh karenanya penelitian ini sangat penting untuk dilaksanakan.

\section{METODE}

Penelitian ini menggunakan jenis penelitian tindakan kelas (PTK) model McKernan. Model penelitian ini menekankan pada evaluasi sebagai dasar pengambilan keputusan selanjutnya (Sanjaya, 2014). Data dari penelitian ini kemudian dianalisis secara deskriptif yaitu dengan menentukan nilai rata-rata prestasi belajar Pendidikan Agama Hindu dengan rumus :

$$
\mathrm{M}=\underline{\mathrm{X}}_{1}+\underline{\mathrm{X}}_{2} \frac{+\mathrm{X}_{3}+\ldots+\mathrm{X}_{\underline{N}}}{\mathrm{~N}}
$$

Keterangan :

$$
\mathrm{M}=\text { Rata }- \text { rata prestasi belajar }
$$

Pendidikan Agama Hindu $\mathrm{X}=$ Skor Prestasi belajar

Pendidikan Agama Hindu

$$
\mathrm{N}=\text { Banyaknya siswa }
$$

Penggunaan Model Pembelajaran Problem Based Learning Berbantuan Kartu "Sulang Maya” Dalam Meningkatkan Aktivitas Dan Hasil Belajar Pendidikan Agama Hindu Siswa Kelas VII A SMP Negeri 1 Bangli Tahun Pelajaran 2018/2019

\begin{tabular}{ll|l} 
SMP Negeri 1 Bangli dan STAHN Mpu Kuturan & I Nengah Asrama Juta Ningrat, S.Ag, M.Fil.H dan
\end{tabular} Singaraja Ayu Veronika Somawati, M.Fil.H. 
Kualifikasi hasil belajar Pendidikan Agama Hindu ditentukan dengan kriteria sebagai berikut :

$$
\begin{aligned}
& 86-100=\text { Sangat baik } \\
& 71-85=\text { Baik } \\
& 56-70=\text { Cukup } \\
& 41-55=\text { Kurang } \\
& <40=\text { Sangat kurang }
\end{aligned}
$$

\begin{tabular}{|c|c|c|c|}
\hline \multicolumn{2}{|c|}{ Konversi nilai akhir } & \multirow{2}{*}{$\begin{array}{c}\text { Predikat } \\
\text { (Pengetahuan } \\
\text { dan } \\
\text { Keterampilan) }\end{array}$} & \multirow[b]{2}{*}{ Sikap } \\
\hline $\begin{array}{l}\text { Skala } \\
100\end{array}$ & Skala 4 & & \\
\hline $96-100$ & 4 & $\mathbf{A}$ & \multirow{2}{*}{ SB } \\
\hline $87-95$ & 3.66 & A- & \\
\hline $79-86$ & $\mathbf{3 . 3 3}$ & B+ & \multirow{3}{*}{ B } \\
\hline $70-78$ & 3.00 & B & \\
\hline $62-69$ & 2.66 & B- & \\
\hline $54-61$ & 2.33 & $\mathrm{C}+$ & \multirow{3}{*}{ C } \\
\hline $45-53$ & 2 & $\mathbf{C}$ & \\
\hline $37-44$ & 1.66 & C- & \\
\hline $29-36$ & $\mathbf{1 . 3 3}$ & D+ & \multirow{2}{*}{ K } \\
\hline $1-28$ & 1 & D & \\
\hline
\end{tabular}

(Diadopsi dari

BSNP, 2013)

\section{Tabel konversi nilai}

Kriteria keberhasilan rata-rata skor prestasi belajar Penda Hindu adalah sesuai KKM Kelas yang telah ditetapkan yaitu $72(\mathrm{C})$

Daya serap dan ketuntasan belajar siswa dicari dengan rumus sebagai berikut: $\mathrm{DS}=\mathrm{M} \times 1 \%$

$\mathrm{KB}=\underline{\text { siswamemperoleh skor } \geq 71 \times 100 \%}$ $N$

Keterangan :

DS = Daya serap

$\mathrm{M}=$ Rata-rata skor hasil belajar

Pendidikan Agama Hindu

$\mathrm{KB}=$ Ketuntasan belajar

$\mathrm{N}=$ Banyaknya siswa
Kriteria keberhasilan daya serap dan ketuntasan belajar yang ditetapkan dalam penelitian ini adalah :

Daya serap ( DS ) $\geq 71 \%$

Ketuntasan belajar ( KB ) $\geq 85 \%$

Sedangkan untuk data aktifitas siswa dalam proses pembelajaran agama Hindu menggunakan langkah-langkah analisis aktivitas belajar siswa menurut Trianto (2011: 243) adalah sebagai berikut :

a. Penentuan rata-rata aktivitas belajar klasikal dengan rumus :

$$
\mathrm{AP}=\underset{\underline{\Sigma} \mathrm{p}}{\underline{\Sigma}} \mathrm{P} \times 100 \%
$$

Keterangan :

$$
\begin{aligned}
& \text { AP : Nilai persen yang dicari } \\
& \begin{array}{l}
\sum \quad \mathrm{P}: \text { Banyaknya siswa } \\
\text { melakukan aktivitas }
\end{array} \\
& \sum \text { p: Jumlah seluruh siswa (28) }
\end{aligned}
$$

b. Penentuan katagori aktivitas belajar klasikal

Aktivitas belajar siswa secara klasikal digolongkan ke dalam kriteria sebagai berikut :

\section{Tabel 1}

Kriteria Penggolongan Aktivitas Belajar

\begin{tabular}{|c|c|}
\multicolumn{2}{c}{ Siswa } \\
\hline Interval & Kriteria \\
\hline $90-100$ & Sangat Aktif \\
\hline $75-89$ & Aktif \\
\hline $55-74$ & Cukup Aktif \\
\hline $30-54$ & Kurang Aktif \\
\hline $0-29$ & Sangat Kurang Aktif \\
\hline
\end{tabular}

Kriteria keberhasilan aktivitas belajar siswa dalam penelitian ini adalah apabila aktivitas belajar siswa minimal tergolong Aktif.

Penggunaan Model Pembelajaran Problem Based Learning Berbantuan Kartu "Sulang Maya” Dalam Meningkatkan Aktivitas Dan Hasil Belajar Pendidikan Agama Hindu Siswa Kelas VII A SMP Negeri 1 Bangli Tahun Pelajaran 2018/2019

SMP Negeri 1 Bangli dan STAHN Mpu Kuturan I Nengah Asrama Juta Ningrat, S.Ag, M.Fil.H dan Singaraja 
Penelitian ini dilaksanakan dalam dua siklus dengan langkah-langkah kegiatan meliputi empat tahapan yakni perencanaan, pelaksanaan tindakan, observasi dan repleksi. Pelaksanaan tahapan tersebut terus dilakukan secara berulang-ulang yaitu berdasarkan hasil refreksi siklus sebelumnya kemudian diadakan perbaikan untuk pelaksanaan siklus berikutnya dimana dalam tiap-tiap siklus diterapkan pembelajaran Pendidikan Agama Hindu dengan model pembelajaran Problem Based Learning berbantuan kartu sulang-maya.

\section{PEMBAHASAN}

Adapun hasil Penelitian tindakan kelas (PTK) dapat peneliti uraikan dalam tahapan siklus-siklus pembelajaran yang dilakukan. Jenis data yang dikumpulkan tiap-tiap akhir siklus adalah: data hasil belajar siswa kelas VII A SMP Negeri 1 Bangli dengan penggunaan model pembelajaran problem based learning berbantuan karu sulang-maya pada pembelajaran Pendidikan Agama Hindu. Berikut ini akan disajikan hasil penelitian secara berturut-turut sesuai dengan masingmasing siklus penelitian.

\section{A. SIKLUS I}

\section{Perencanaan}

Langkah-langkah yang dilaksanakan dalam tahap perencanaan pada siklus pertama adalah sebagai berikut :

a. Melakukan analisis kurikulum untuk mengetahui kompetensi dasar yang akan disampaikan kepada siswa dalam pembelajaran.

b. Membuat Rencana Pelaksananaan Pembelajaran (RPP) dengan mengacu pada tindakan (treament) yang diterapkan pada PTK.

c. Merancang pembelajaran problem based learning berbantuan kartu Sulang-maya.

d. Membuat Lembar Kerja Siswa

e. Membuat instrument yang digunakan dalam siklus PTK.

f. Menyusun alat evaluasi pembelajaran.

\section{Pelaksanaan (Acting)}

Setelah perencanaan disesuaikan dengan situasi dan kondisi serta waktu yang tersedia, maka dilakukan tindakan dengan materi pembelajaran yaitu Aspek yadnya, Kompetensi Dasar, KI-3: Memahami kualitas Panca Yadnya dalam kehidupan, dan Kompetensi Dasar KI- 4: Menyajikan contoh Panca Yadnya yang tergolong satvika, rajasika dan tamasika. Kegiatan yang dilaksanakan dalam tahap ini secara kronologis dilaksanakan sesuai dengan Rencana Pelaksanaan Pembelajaran (RPP) dengan menggunakan model Problem Based Learning berbantuan kartu sulangmaya yang telah di buat sebelumnya. Dengan langkah-langkah sebagai berikut:

\section{a. Pendahuluan}

(1) Apersepsi: mengucapkan salam panganjali, duduk hening dengan mengucapkan doa-doa, dan absensi siswa,

(2) Motivasi: memberikan motivasi tentang pembelajaran yadnya,

(3) Menyampaikan tujuan pembelajaran.

\section{b. Kegiatan Inti}

(1) Mengorientasikan siswa pada masalah

- Mengorientasi siswa pada masalah, tahap ini untuk memfokuskan siswa

Penggunaan Model Pembelajaran Problem Based Learning Berbantuan Kartu “Sulang Maya” Dalam Meningkatkan Aktivitas Dan Hasil Belajar Pendidikan Agama Hindu Siswa Kelas VII A SMP Negeri 1 Bangli Tahun Pelajaran 2018/2019

SMP Negeri 1 Bangli dan STAHN Mpu Kuturan I Nengah Asrama Juta Ningrat, S.Ag, M.Fil.H dan Singaraja 
mengamati masalah yang menjadi objek pembelajaran.

- Peserta didik menyimak gambargambar pelaksanaan upacara yadnya yang dibagikan oleh guru secara acak.

- Siswa diajak meyimak kembali gambar - gambar pelaksanaan kegiatan upacara keagamaan, dan dari kegiatan menyimak itu peserta didik termotivasi untuk mengetahui lebih jauh tentang nama-nama kegiatan pelaksanaan upacara agama tersebut.

(2) Mengorganisasikan kegiatan pembelajaran

- Guru mengarahkan siswa membentuk kelompok belajar yang terdiri dari empat sampai dengan lima orang.

- Siswa secara berkelompok diarahkan untuk bertanya berdasarkan pengamatan yang telah dilakukan.

(3) Membimbing penyelidikan mandiri dan kelompok

- Siswa diarahkan kembali membaca buku teks Pendidikan Agama Hindu dan Budi Pekerti dan sumber lain, terkait dengan materi memahai ajaran yadnya.

- Siswa mencari informasi untuk melakukan percobaan dalam memperoleh data untuk menjawab dan merumuskan masalah yang diberikan dalam kegitan pembelajaran melalui potonganpotongan kartu yang berisi gambargambar pelaksanaan upacara yadnya.

- Guru membimbing siswa untuk menyusun ulang pembagian dan contoh-contoh pelaksanaan yadnya, berdasarkan potongan-potongan kartu yang berisi gambar-gambar pelaksanaan yadnya.

(4) Mengenbangkan dan menyajikan hasil

- Siswa mengasosiasi data yang ditemukan, untuk menjawab dan menyusun ulang materi yadnya berdasarkan pertanyaan-pertanyaan yang disajikan dari kegiatan mengamati gambar, membaca teks, dan berdiskusi dengan kelompok.

- Siswa menyusun ulang materi yandnya, dengan mengisi pertanyaan-pertanyaan yang terdapat pada potongan-potongan kartu sesuai dengan petunjuk yang diberikan oleh guru.

- Siswa secara berkelompok menyampaikan hasil yang ditemukan dari aktivitas pembelajaran di depan kelas secara bergilir.

(5) Analisis dan Evaluasi pemecahan masalah

- Siswa secara berkelompok mengevaluasi bersama guru tentang uraian jawaban yang telah dikumpulkan.

- Siswa diarahkan untuk memeriksa kembali hasil yang telah dibuat secara individu dan berkelompok berdasarkan buku pegangan siswa dan sumber refrensi lain.

- Salah satu siswa diberikan kesempatan untuk menampilkan kembali hasil pembelajaranya, dengan mendemontrasikan hasil pembelajaran berdasarkan hasil analisis dan evaluasi.

\section{c. Kegitan Penutup.}

(1) Siswa bersama guru menyimpulkan hasil pembelajaran

Penggunaan Model Pembelajaran Problem Based Learning Berbantuan Kartu "Sulang Maya" Dalam Meningkatkan Aktivitas Dan Hasil Belajar Pendidikan Agama Hindu Siswa Kelas VII A SMP Negeri 1 Bangli Tahun Pelajaran 2018/2019

SMP Negeri 1 Bangli dan STAHN Mpu Kuturan I Nengah Asrama Juta Ningrat, S.Ag, M.Fil.H dan Singaraja 
(2) Guru mengevaluasi hasil belajar siklus I

(3) Memberikan penguatan atau kesimpulan secara bersama-sama dan refleksi

(4) Merancang pembelajaran berikutnya.

\begin{tabular}{|l|c|c|c|c|}
\hline $\begin{array}{l}\text { yang diberikan } \\
\text { oleh guru. }\end{array}$ & & & \\
\hline & Rata-rata & 14 & 71 & $\begin{array}{c}\text { Cukup } \\
\text { Aktif }\end{array}$ \\
\hline
\end{tabular}

b. Data yang diperoleh dari hasil tes belajar siswa untuk mengetahui peningkatan hasil belajar siswa dengan penggunaan model pembelajaran problem based learning berbantuan kartu sulang-maya pada pelaksanaan siklus I didasarkan pada rata-rata (Mean), Daya serap (DS), dan Ketuntasan Balajar ( KB ) sebagai berikut:

Rata (M) hasil belajar siswa yang Aktivitas Belajar Siswa Siklus I

\begin{tabular}{|c|l|c|c|c|}
\hline No & \multicolumn{1}{|c|}{$\begin{array}{c}\text { Indikator } \\
\text { Aktivitas/ } \\
\text { Sikap sosial }\end{array}$} & $\Sigma$ & $\%$ & Kriteria \\
\hline 1. & $\begin{array}{l}\text { Menngamati } \\
\text { masalah yang } \\
\text { diberikan oleh } \\
\text { guru }\end{array}$ & 18 & 90,3 & $\begin{array}{c}\text { Sangat } \\
\text { Aktif }\end{array}$ \\
\hline 2. & $\begin{array}{l}\text { Memecahkan } \\
\text { masalah baik } \\
\text { menanya } \\
\text { maupun } \\
\text { menjawab }\end{array}$ & 12 & 65,6 & $\begin{array}{c}\text { Cukup } \\
\text { Aktif }\end{array}$ \\
\hline 3. & $\begin{array}{l}\text { Mengolah data } \\
\text { dan melakukan } \\
\text { penyelidikan }\end{array}$ & 17 & 85,8 & Aktif \\
\hline 4. & $\begin{array}{l}\text { Mengembangkan } \\
\text { dan mengolah } \\
\text { hasil 14 } \\
\text { pembelajaran }\end{array}$ & 70,4 & Cukup \\
\hline 5. & $\begin{array}{l}\text { Mengerjakan } \\
\text { tugas } \\
\text { mengkomonikan } \\
\text { hasil dan } \\
\text { pembelajaran }\end{array}$ & 10 & 50,0 & Kurang \\
Aktif
\end{tabular}
belajar dengan model pembelajaran problem based learning berbantuan kartu sulang-maya dapat disajikan dengan rumus sebagai berikut :

$$
\begin{aligned}
\mathrm{M} & =\underline{\mathrm{X}}_{1}+\underline{\mathrm{X}}_{2}+\underline{\mathrm{X}}_{3}+\ldots+\mathrm{X}_{\underline{\mathrm{N}}} \\
\mathrm{M} & =\frac{1390}{20} \\
& =\mathbf{6 9 , 3 5}=(\mathrm{B}-)
\end{aligned}
$$

$$
\begin{aligned}
\mathrm{DS} & =\mathrm{M} \times 1 \% \\
& =69,35 \times 1 \% \\
& =\mathbf{6 9}, \mathbf{3 5} \%=\mathbf{( B -})
\end{aligned}
$$

$\mathrm{KB}=$ Banyaknya siswa yang memperoleh skor $\geq 72 \times 100 \%$

$$
\begin{aligned}
& =\frac{12 \times 100 \%}{20} \\
& =\mathbf{6 0 , 6 8 \%}
\end{aligned}
$$

Keterangan :

$$
\begin{aligned}
& \mathrm{DS}=\text { Daya serap } \\
& \mathrm{M}=\text { Rata-rata skor hasil belajar }
\end{aligned}
$$

Pendidikan Agama Hindu

$$
\begin{aligned}
& \mathrm{KB}=\text { Ketuntasan belajar } \\
& \mathrm{N}=\text { Banyaknya siswa }
\end{aligned}
$$

Penggunaan Model Pembelajaran Problem Based Learning Berbantuan Kartu "Sulang Maya" Dalam Meningkatkan Aktivitas Dan Hasil Belajar Pendidikan Agama Hindu Siswa Kelas VII A SMP Negeri 1 Bangli Tahun Pelajaran 2018/2019

SMP Negeri 1 Bangli dan STAHN Mpu Kuturan I Nengah Asrama Juta Ningrat, S.Ag, M.Fil.H dan Singaraja 
VOLUME 8 NOMOR 1 MARET 2021

ISSN : 2355-5696 (CETAK)

ISSN : 2655-0156 (ONLINE)

http://ejournal.ihdn.ac.id/index.php/GW
Dari analisis data hasil belajar siswa di atas dapat di uraikan sebagai berikut :

a. Rata- rata hasil belajar siswa pada siklus I adalah 69,35. (B-) Hal ini berarti belum mencapai kriteria ketuntasan rata-rata hasil belajar yang telah ditentukan yaitu 72 .

b. Daya serap belajar siswa mencapai 69,35\%. Hal ini menunjukkan bahwa Daya Serap hasil belajar siswa belum memenuhi target yang ditetapkan dalam penelitian ini yaitu : Daya serap (DS ) $\geq 75 \%$

c. Ketuntasan belajar Siswa (KB) mencapai angka $60,68 \%$, hal ini berarti belum memenuhi kriteria yang ditentukan yaitu : Ketuntasan belajar ( KB ) $\geq 85 \%$.

Berdasarkan data hasil belajar maka dapat ditentukan kategori hasil belajar siswa pada siklus II, seperti pada tabel berikut :

Tabel 2

Kategori Hasil Belajar Siklus I

\begin{tabular}{|c|c|c|c|c|}
\hline $\begin{array}{l}\mathbf{N} \\
\mathbf{0}\end{array}$ & $\begin{array}{l}\text { Sk } \\
\text { or }\end{array}$ & $\begin{array}{c}\text { Frekue } \\
\text { nsi }\end{array}$ & $\begin{array}{c}\text { Prosent } \\
\text { ase }\end{array}$ & $\begin{array}{c}\text { Kateg } \\
\text { ori }\end{array}$ \\
\hline 1 & $\begin{array}{c}86 \\
- \\
100\end{array}$ & 0 & 0 & $\begin{array}{c}\text { Sangat } \\
\text { baik }\end{array}$ \\
\hline 2 & $\begin{array}{c}71 \\
- \\
85\end{array}$ & 12 & 59,62 & Baik \\
\hline 3 & $\begin{array}{c}56 \\
- \\
70\end{array}$ & 6 & 29,38 & Cukup \\
\hline 4 & $\begin{array}{c}41 \\
- \\
55\end{array}$ & 2 & 10,00 & $\begin{array}{c}\text { Kuran } \\
\mathrm{g}\end{array}$ \\
\hline
\end{tabular}

\begin{tabular}{|c|c|c|c|c|}
\hline 5 & $\begin{array}{c}0- \\
40\end{array}$ & 0 & 0 & $\begin{array}{c}\text { Sangat } \\
\text { kurang }\end{array}$ \\
\hline \multicolumn{2}{|c|}{ Jumlah } & 20 & 100 & \\
\hline
\end{tabular}

4. Refleksi dan Perencanaan Ulang (Reflecting and Replaning)

Pada saat awal siklus pertama pelaksanaan belum sesuai dengan rencana. Hal ini disebabkan karena :

a. Guru terlalu terburu-buru dengan membagikan gambar-gambar pelaksanaan yajna tanpa memberikan penggambaran materi terlebih dahulu

b. Ada sebagian siswa yang belum terfokus perhatianya pada materi serta model pembelajaran yang dilakukan

c. Tanggung jawab siswa dalam mengerjakan tugas masih kurang disebabkan karena siswa masih mempunyai anggapan bahwa guru akan melakukan penilaian hanya melalui tes ulangan saja sehingga dalam proses dan mengomonikan masalah terabaikan.

d. Aktivitas siswa dalam pembelajaran kurang karena siswa belum optimal untuk berinisiatif memberikan tanggapan terhadap pekerjaan temannya yang disebabkan oleh masih kurangnya pemahaman terhadap materi dan siswa takut salah.

Untuk mengatasi masalah di atas dilakukan upaya sebagai berikut :

a. Guru memberikan penggabaran terlebih dahulu tentang materi yajna

b. Menyajikan materi yajna dalam bentuk potongan-potongan kartu dan membagikan gambar-gambar

Penggunaan Model Pembelajaran Problem Based Learning Berbantuan Kartu "Sulang Maya” Dalam Meningkatkan Aktivitas Dan Hasil Belajar Pendidikan Agama Hindu Siswa Kelas VII A SMP Negeri 1 Bangli Tahun Pelajaran 2018/2019

SMP Negeri 1 Bangli dan STAHN Mpu Kuturan I Nengah Asrama Juta Ningrat, S.Ag, M.Fil.H dan Singaraja 
pelaksanaan yajna lebih banyak dan bervariasi

c. Guru secara intensif memberi pengertian kepada siswa agar mereka bertanggung jawab dalam mengerjakan tugas, pasang ulang materi yajna dan gambar-gambar pelaksanaan yajna sesuai dengan pembagian yajna

d. Memotivasi siswa agar aktif dalam proses pembelajaran, berani mengemonikasikan dan tidak takut salah.

e. Memberikan reward bagi mereka yang berhasil dan terbaik dalam hasil belajarnya.

\section{B. SIKLUS KEDUA}

Seperti pada siklus pertama, prosedur penelitian pada siklus kedua ini juga terdiri dari empat tahapan yaitu : Perencanaan (Planing), Pelaksanaan (Acting), Observasi (Observation) dan Refleksi (Reflecting)

\section{Perencanaan (Planing)}

Langkah-langkah

yang

dilaksanakan dalam tahap perencanaan dalam siklus kedua dilaksanakan berdasarkan replaning pada silkus I, yaitu:

a. Guru memberikan penggambaran tentang materi yadnya

b. Menyajikan materi yajna dalam bentuk potongan-potongan kartu dan membagikan gambargambar pelaksanaan yajna yang lebih banyak, agar siswa lebih kreatif dan menarik dalam pasang ulang materi yadnya

c. Guru secara intensif memberi pengertian kepada siswa agar mereka bertanggung jawab dalam mengumpulkan datadata dan mengerjakan tugastugas yang diberikan melalui pasangan ulang materi yajna dalam potongan-potongan kartu yang didukung dengan gamabar contoh -contoh dari pelaksanaan uapacara yajna, karena hal itu akan dijadikan dasar bagi guru dalam penilaian proses belajar siswa.

d. Memotivasi siswa agar aktif dalam proses pembelajaran, berani mengkomonikasikan, mengemukakan pendapat dan tidak takut salah.

e. Memberikan reward bagi mereka yang berhasil dan terbaik dalam hasil belajarnya.

\section{Pelaksanaan Tindakan (Acting)}

Kegiatan yang dilaksanakan dalam tahap ini masih tetap berpedoman pada langkah-langkah siklus I dengan merevisi beberapa hal yang didasarkan pada replaning pada siklus I. Adapun materi pembelajaran yaitu Aspek Yanya, Kompetensi Dasar, KI-3: Memahami ajaran yadnya dan kualitas yadnya, dan Kompetensi Dasar KI-4: Menyebutkan contoh yadnya yang bersifat satvika, rajasika dan tamasika. Kegiatan yang dilaksanakan dalam tahap ini secara kronologis dilaksanakan sesuai dengan Rencana Pelaksanaan Pembelajaran (RPP) yang telah dibuat sebelumnya.

\section{Observasi dan Evaluasi (Observation and \\ Evaluation)}

a. Hasil Observasi aktivitas siswa dalam Proses Belajar Mengajar (PBM)

Penggunaan Model Pembelajaran Problem Based Learning Berbantuan Kartu “Sulang Maya” Dalam Meningkatkan Aktivitas Dan Hasil Belajar Pendidikan Agama Hindu Siswa Kelas VII A SMP Negeri 1 Bangli Tahun Pelajaran 2018/2019

SMP Negeri 1 Bangli dan STAHN Mpu Kuturan I Nengah Asrama Juta Ningrat, S.Ag, M.Fil.H dan Singaraja 
selama siklus kedua dapat dilihat pada tabel berikut :

Tabel 3

Aktivitas Belajar Siswa Siklus II

\begin{tabular}{|c|c|c|c|c|}
\hline No & $\begin{array}{c}\text { Indikator } \\
\text { Aktivitas/ } \\
\text { Sikap sosial }\end{array}$ & $\Sigma$ & $\begin{array}{c}\% \\
\text { (Prose } \\
\text { ntase) }\end{array}$ & Kriteria \\
\hline 1. & $\begin{array}{l}\text { Menngamat } \\
\text { i masalah } \\
\text { yang } \\
\text { diberikan } \\
\text { oleh guru }\end{array}$ & 20 & 100 & Aktif \\
\hline 2. & $\begin{array}{l}\text { Memecahka } \\
\mathrm{n} \text { masalah } \\
\text { baik } \\
\text { menanya } \\
\text { maupun } \\
\text { menjawab }\end{array}$ & 18 & 9,00 & $\begin{array}{c}\text { Sangat } \\
\text { Aktif }\end{array}$ \\
\hline 3. & $\begin{array}{l}\text { Mengolah } \\
\text { data dan } \\
\text { melakukan } \\
\text { penyelidika } \\
\text { n }\end{array}$ & 20 & 100 & $\begin{array}{c}\text { Sangat } \\
\text { Aktif }\end{array}$ \\
\hline 4. & $\begin{array}{l}\text { Mengemban } \\
\text { gkan dan } \\
\text { mengolah } \\
\text { hasil } \\
\text { pembelajara } \\
\text { n }\end{array}$ & 16 & 8,00 & $\begin{array}{c}\text { Sangat } \\
\text { Aktif }\end{array}$ \\
\hline 5. & $\begin{array}{l}\text { Mengerjaka } \\
\mathrm{n} \text { tugas dan } \\
\text { mengkomon } \\
\text { ikan hasil } \\
\text { pembelajara } \\
\mathrm{n} \text { yang } \\
\text { diberikan } \\
\text { oleh guru. }\end{array}$ & 20 & 100 & $\begin{array}{c}\text { Sangat } \\
\text { Aktif }\end{array}$ \\
\hline & Rata-rata & 18.8 & 94, & $\begin{array}{c}\text { Sangat } \\
\text { Aktif }\end{array}$ \\
\hline
\end{tabular}

b. Data yang diperoleh dari hasil tes belajar siswa untuk mengetahui peningkatan hasil belajar siswa dengan penggunaan model pembelajaran problem based learning pada pelaksanaan siklus II didasarkan pada rata - rata (Mean), Daya serap (DS), dan Ketuntasan Balajar (KB) sebagai berikut :

Rata (M) hasil belajar siswa yang belajar dengan dapat disajikan dengan rumus sebagai berikut :

$$
\begin{aligned}
& \mathrm{M}=\underline{\mathrm{X}}_{\underline{1}}+\mathrm{X}_{\underline{2}}+\mathrm{X}_{\underline{3}}+\ldots+\mathrm{X}_{\underline{\mathrm{N}}} \\
& M=\underline{1656} \\
& 20 \\
& =82,08=(B+) \\
& \mathrm{DS}=\mathrm{M} \times 1 \% \\
& =82,08 \times 1 \% \\
& =82,08 \%(\mathrm{~B}+) \\
& =\underline{19 \times 100 \%} \\
& 20 \\
& =95,00 \%
\end{aligned}
$$

Keterangan :

$$
\begin{aligned}
& \mathrm{DS}=\text { Daya serap } \\
& \mathrm{M}=\text { Rata-rata skor hasil belajar }
\end{aligned}
$$

Pendidikan Agama Hindu

$$
\mathrm{KB}=\text { Ketuntasan belajar }
$$$$
\mathrm{N}=\text { Banyaknya siswa }
$$

Dari analisis data hasil belajar siswa di atas dapat di uraikan sebagai berikut :

a. Rata- rata hasil belajar siswa pada siklus II adalah 82,08, (B+) Hal ini menunjukkan telah tercapainya kriteria ketuntasan rata-rata hasil belajar yang telah ditentukan yaitu 72 .

b. Daya serap belajar siswa mencapai $82,08 \%(\mathrm{~B}+)$ Hal ini menunjukkan bahwa Daya Serap hasil belajar siswa

Penggunaan Model Pembelajaran Problem Based Learning Berbantuan Kartu "Sulang Maya” Dalam Meningkatkan Aktivitas Dan Hasil Belajar Pendidikan Agama Hindu Siswa Kelas VII A SMP Negeri 1 Bangli Tahun Pelajaran 2018/2019

SMP Negeri 1 Bangli dan STAHN Mpu Kuturan I Nengah Asrama Juta Ningrat, S.Ag, M.Fil.H dan Singaraja 
telah memenuhi target yang ditetapkan dalam penelitian ini yaitu : Daya serap (DS) $\geq 75 \%$

c. Ketuntasan belajar Siswa (KB) mencapai angka 95,00\%. Hal ini menunjukkan tingkat ketercapaian ketuntasan belajar (KB) lebih besar dari $85 \%$ sehingga pembelajaran dengan model pembelajaran problem besed learning berbatuan kartu sulangmaya dianggap tuntas.

Tabel 4

Kategori Hasil Belajar Siklus II

\begin{tabular}{|c|c|c|c|c|}
\hline No & Skor & Frekuensi & Prosentase & Kategori \\
\hline 1 & $\begin{array}{l}86- \\
100 \\
\end{array}$ & 5 & 25,00 & $\begin{array}{c}\text { Sangat } \\
\text { baik }\end{array}$ \\
\hline 2 & $\begin{array}{c}71- \\
85\end{array}$ & 14 & 70,00 & Baik \\
\hline 3 & $\begin{array}{c}56- \\
70\end{array}$ & 1 & 5,00 & Cukup \\
\hline 4 & $\begin{array}{c}41- \\
55\end{array}$ & 0 & 0 & Kurang \\
\hline 5 & $\begin{array}{l}0- \\
40\end{array}$ & 0 & 0 & $\begin{array}{l}\text { Sangat } \\
\text { kurang }\end{array}$ \\
\hline \multicolumn{2}{|c|}{ Jumlah } & 20 & 100 & \\
\hline
\end{tabular}

\section{Refleksi (Reflection)}

a. Pembelajaran dengan model pembelajaran problem based learning sudah berjalan optimal.

b. Aktivitas belajar siswa dalam proses pembelajaran sudah semakin membaik, siswa sudah berani mengemonikasikan, mengemukakan pendapat dan tidak takut salah.

c. Setiap siswa sudah memiliki tanggung jawab dalam pegerjaan tugas. e. Hasil belajar siswa sudah mencapai standar ketuntasan minimal yang telah ditetapkan.

Tabel 5

Perbandingan Hasil Siklus I dengan

Siklus II

\begin{tabular}{|c|c|c|c|c|c|c|}
\hline \multirow[b]{2}{*}{$\begin{array}{l}\mathrm{N} \\
\mathrm{o}\end{array}$} & \multirow[b]{2}{*}{ Indikator } & \multicolumn{2}{|c|}{ Siklus I } & \multicolumn{2}{|c|}{ Siklus II } & \multirow{2}{*}{$\begin{array}{l}\text { Selisih } \\
\text { skor } \\
\text { peroleh } \\
\text { an }\end{array}$} \\
\hline & & Skor & Kategori & Skor & $\begin{array}{l}\text { kate } \\
\text { gori }\end{array}$ & \\
\hline 1 & $\begin{array}{l}\text { Rata-rata } \\
\text { Keaktifa } \\
\text { n Belajar }\end{array}$ & 71 & $\begin{array}{l}\text { Cukup } \\
\text { Aktif }\end{array}$ & 94, & $\begin{array}{c}\text { Sang } \\
\text { at } \\
\text { Akti } \\
\text { f }\end{array}$ & 23 \\
\hline 2 & $\begin{array}{l}\text { Hasil } \\
\text { Belajar } \\
\text { 1) Rata- } \\
\text { Rata } \\
\text { 2) } \begin{array}{l}\text { Daya } \\
\text { Serap }\end{array} \\
\text { 3) Ketu } \\
\text { ntasa } \\
\text { n }\end{array}$ & $\begin{array}{c}69,3 \\
5 \\
69,3 \\
5 \% \\
60,6 \\
8 \%\end{array}$ & $\begin{array}{l}\text { Cukup } \\
\text { Cukup } \\
\text { Cukup }\end{array}$ & $\begin{array}{c}82,0 \\
8 \\
82,0 \\
8 \% \\
95,0 \\
0 \%\end{array}$ & $\begin{array}{c}\text { Baik } \\
\text { Baik } \\
\text { Sang } \\
\text { at } \\
\text { Baik }\end{array}$ & $\begin{array}{c}12,73 \\
12,73 \% \\
34,32 \%\end{array}$ \\
\hline
\end{tabular}

Penggunaan model pembelajaran problem based learning berbantuan kartu sulang maya mendapat tanggapan posotif dari siswa. Hal ini dapat dilihat dari kecendrungan meningkatnya aktivitas belajar siswa yang secara tidak langsung berimplikasi terhadap peningkatan hasil belajar siswa dari siklus I ke siklus II. Pada siklus I, aktivitas belajar siswa belum berlangsung dengan baik, sehingga masih perlu ditingkatkan. Hal ini dapat dilihat dari lima indikator aktivitas belajar, ada tiga indikator yang belum berlangsung dengan baik, yaitu : 1) Mengamati dan mengidentifikasikan masalah yang diberikan oleh guru, 2) Mengikuti

Penggunaan Model Pembelajaran Problem Based Learning Berbantuan Kartu "Sulang Maya” Dalam Meningkatkan Aktivitas Dan Hasil Belajar Pendidikan Agama Hindu Siswa Kelas VII A SMP Negeri 1 Bangli Tahun Pelajaran 2018/2019

SMP Negeri 1 Bangli dan STAHN Mpu Kuturan I Nengah Asrama Juta Ningrat, S.Ag, M.Fil.H dan Singaraja 
pelaksanaan pembelajaran dan diskusi, 3) Mengemukakan pendapat dan bertanya. Hal ini disebabkan oleh beberapa faktor diantaranya : a) Siswa takut salah dalam mengidentifikasikan masalah, b) masih adanya anggapan dari siswa bahwa siswa menjawab bila diberikan pertanyaan oleh guru dan belum terbiasa berdiskusi, sehingga kalau tidak disuruh maka mereka akan pasif.

Aktivitas belajar pada siklus II mengalami peningkatan dibandingkan siklus I. Hal ini dapat dilihat dari indikator aktivitas siswa pada siklus I yang belum berlangsung baik sudah terjadi perubahan ke arah yang lebih baik. Siswa sudah berani bertanya dan menjawab pertanyaan guru dan teman, memperhatikan dan mengidintifikasikan masalah yang diberikan oleh guru walaupun tanpa diperintah. Secara keseluruhan terjadi peningkatan aktivitas belajar siswa dari siklus I ke Siklus II. Berdasarkan perbandingan yang dilakukan rata-rata skor aktivitas siswa pada siklus I mencapai skor 14 dengan prosentase $71 \%$ kriteria cukup aktif dan pada siklus II mencapai rata-rata skor 18,8 dengan prosentase 94\% kriteria sangat aktif dengan demikian terjadi peningkatan sebesar 23\%.

Sedangkan hasil yang diperoleh dari tes hasil belajar menunjukkan bahwa kemampuan siswa dalam mengikuti pelajaran sudah cukup baik. Pada siklus I rata-rata hasil belajar siswa dengan perolehan angka 69,35 (B-) yang menunjukkan klasifikasi cukup, daya serap dengan angka 69,35\% dengan klasifikasi cukup, dan ketuntasan belajar 60,68\% klasifikasi cukup, dengan demikian bahwa hasil belajar pendidikan agama Hindu pada siswa kelas VII SMP Negeri 1 Bangli pada siklus pertama adalah cukup baik. Pada siklus II diperoleh hasil dari Rata-rata hasil belajar siswa adalah 82,08 dengan kategori baik, daya serap siswa menunjukkan $82,08 \%$, (B+) dengan kategori baik dan ketuntasan belajar menunjukkan 95,00\% dengan kategori sangat baik.

Setelah dibandingkan nilai siklus I dan Siklus II terjadi kenaikan yang signifikan yaitu pada siklus I dengan angka 1387 dan pada siklus II dengan angka 1656 hal ini menunjukkan peningkatan dari siklus I ke Siklus II sebesar 269 poin. Dilihat dari rata-rata (Mean) pada siklus I dengan angka 69,35 (B-) dan pada siklus II dengan angka 82,08 (B+) terdapat peningkatan rata-rata 12,73 poin Dilihat dari daya serap pada siklus I dengan angka $69,35 \%$ dan pada siklus II dengan angka $82,08 \%$ terdapat peningkatan $12,73 \%$, sedangkan dilihat dari ketuntasan belajar pada siklus I mencapai angka $60,68 \%$ dan ketuntasan belajar pada siklus II mencapai angka 95,00 \% maka terdapat peningkatan $35,68 \%$.

Peningkatan aktivitas dan hasil belajar siswa kelas VII A SMP Negeri 1 Bangli tahun Pelajaran 2018/2019 setelah menggunakan metode pembelajaran problem based learning berbantuan kartu sulang maya ini terjadi karena siswa disajikan permasalahan yang kontekstual melalui media kartu tersebut sehingga materi pembelajaran menjadi dekat dengan kehidupan siswa sehari-hari. Selain itu, siswa juga diberikan kesempatan untuk mampu mengidentifikasi masalahnya sendiri, aktif menjelaskan pengetahuan dan pemahaman mereka mengenai materi yadnya serta berdiskusi dengan rekan sejawatnya sehingga siswa memiliki pemahaman yang utuh mengenai materi yadnya tersebut. Dengan demikian penggunaan model pembelajaran problem

Penggunaan Model Pembelajaran Problem Based Learning Berbantuan Kartu "Sulang Maya” Dalam Meningkatkan Aktivitas Dan Hasil Belajar Pendidikan Agama Hindu Siswa Kelas VII A SMP Negeri 1 Bangli Tahun Pelajaran $2018 / 2019$

SMP Negeri 1 Bangli dan STAHN Mpu Kuturan I Nengah Asrama Juta Ningrat, S.Ag, M.Fil.H dan Singaraja Ayu Veronika Somawati, M.Fil.H. 
based learning berbantuan kartu sulang maya, dapat meningkatkan hasil belajar pendidikan agama Hindu pada siswa kelas VII A SMP Negeri 1 Bangli tahun Pelajaran 2018/2019.

\section{PENUTUP}

Berdasarkan hasil Penelitian Tindakan Kelas (PTK) dapat disimpulkan bahwa penggunaan model pembelajaran problem based learning berbantuan kartu sulang maya pada siswa kelas VII A SMP Negeri 1 Bangli tahun pelajaran 2018/2019 dapat meningkatkan aktivitas belajar Pendidikan Agama Hindu. Pada siklus I Aktivitas belajar siswa mencapai skor 14 dengan prosentase $71 \%$ kriteria cukup aktif pada siklus II mencapai rata-rata skor 18,8 dengan prosentase $94 \%$ kriteria sangat aktif dengan demikian terjadi peningkatan sebesar 23\%. Pembelajaran Pendidikan Agama Hindu dengan menggunakan model pembelajaran problem based learning berbantuan kartu sulang maya pada siswa kelas VII A SMP Negeri 1 Bangli tahun pelajaran 2018/2019 juga dapat meningkatkan hasil belajar siswa. Berdasarkan siklus I rata-rata (mean) mencapai angka 69,35 (B-) dan pada siklus II dengan angka 82,08 (B+) terdapat peningkatan rata-rata 12,73 poin. Dilihat dari daya serap pada siklus I dengan angka $69,35 \%$ dan pada siklus II dengan angka $82,08 \%$ terdapat peningkatan $12,73 \%$, sedangkan dilihat dari ketuntasan belajar pada siklus I mencapai angka $60,68 \%$ dan ketuntasan belajar pada siklus II mencapai angka $95,00 \%$ maka terdapat peningkatan $35,68 \%$.

Peningkatan aktivitas dan hasil belajar siswa kelas VII A SMP Negeri 1 Bangli tahun Pelajaran 2018/2019 setelah menggunakan metode pembelajaran problem based learning berbantuan kartu sulang maya ini sejalan dengan pandangan teori kontruktivisme yang menekankan bahwa pengetahuan manusia adalah kontruksi (bentukan) manusia itu sendiri. Bertolak dari pandangan konstruktivisme di atas, maka dalam proses pembelajaran agama Hindu yang dilaksanakan dengan menggunakan metode pembelajaran problem based learning berbantuan kartu sulang maya siswa mampu mengkonstruksi kembali pengetahuan yang diperolehnya dari proses pengamatan siswa itu sendiri terhadap media berupa kartu sulang maya. Dengan demikian, sesuai dengan teori pembelajaran yang mengacu pada teori belajar konstruktivisme siswa mampu mengkonstruksi sendiri pengetahuannya melalui stimulus yang diberikan oleh guru dengan menggunakan kartu sulang maya. Siswa menjadi fokus dan aktif dalam mengorganisasikan pengalaman belajar mereka dalam mengidentifikasikan masalah yang diberikan sehingga aktivitas dan hasil belajarnya menjadi meningkat.

\section{DAFTAR PUSTAKA}

BSNP. 2013. Pedoman Penilaian Hasil Belajar di Sekolah Menengah Pertama. Jakarta: Depdikbud.

Abdullah. 2017. Pendekatan Dan Model Pembelajaran Yang Mengaktifkan Siswa. Edureligia Vol. 01 No. 01, 45-62.

Indrawati Romadhoni, I. K. 2017. Penerapan Model Pembelajaran Problem Based Learning (Pbl) Disertai Media Cd Interaktif Terhadap Hasil Belajar Dan Aktivitas Belajar Siswa Pada Pembelajaran Fisika Sma Di Kabupaten Bondowoso. Jurnal

Penggunaan Model Pembelajaran Problem Based Learning Berbantuan Kartu “Sulang Maya” Dalam Meningkatkan Aktivitas Dan Hasil Belajar Pendidikan Agama Hindu Siswa Kelas VII A SMP Negeri 1 Bangli Tahun Pelajaran 2018/2019

SMP Negeri 1 Bangli dan STAHN Mpu Kuturan I Nengah Asrama Juta Ningrat, S.Ag, M.Fil.H dan Singaraja Ayu Veronika Somawati, M.Fil.H. 
Pembelajaran Fisika Vol. 5 No. 4, 329-336.

Joyce, B., Weil, M., dan Calhoun, E. 2009. Model of teaching; model-model pengajaran. (Edisi Delapan). Yogyakarta: Pustaka Pelajar.

Kemendikbud. 2016. Peraturan Menteri Pendidikan dan Kebudayaan Republik Indonesia Nomor 22 Tahun 2016 Tentang Standar Proses.Jakarta: Kemendikbud

Kemendikbud. 2016. Peraturan Menteri Pendidikan dan Kebudayaan Republik Indonesia Nomor 23 Tahun 2016 Tentang Standar Penilaian Pendidikan. Jakarta: Kemendikbud

Rusman. 2013. Model-Model pembelajaran mmengembangkan Profesionalisme Guru. Jakarta: Rajawali pers.

Sanjaya, Wina. 2014. Penelitian Tindakan Kelas. Jakarta: Prenada Media Group.

Trianto. 2011. Model Pembelajaran

Terpadu. Jakarta : Bumi Aksara.

Wahyuningsih, R. 2019. Peningkatan Hasil Belajar Peserta Didikmelalui Penerapan Perpaduan Model Pembelajaran Problem Based Learning Dan Team Gamestournament. Jurnal Pendidikan Tambusai, 641-647.

Penggunaan Model Pembelajaran Problem Based Learning Berbantuan Kartu “Sulang Maya” Dalam Meningkatkan Aktivitas Dan Hasil Belajar Pendidikan Agama Hindu Siswa Kelas VII A SMP Negeri 1 Bangli Tahun Pelajaran 2018/2019

SMP Negeri 1 Bangli dan STAHN Mpu Kuturan I Nengah Asrama Juta Ningrat, S.Ag, M.Fil.H dan Singaraja Ayu Veronika Somawati, M.Fil.H. 